\title{
Introduction
}

\section{The Stories of the Survivors of the Japanese Military Comfort Girls-Women: The Making of the Memories and Meaning}

\section{Why the 'Story'?}

The oral stories of the surviving victims of the Japanese military comfort girlswomen have been the most appealing evidence in bringing to light the comfort girls-women problem as a social issue in our time and in asking Japan to take responsibility for its actions. It is crucial to include the voices of the survivors in the activism to resolve the issue of the Japanese military comfort girls-women. However, using their testimonies in attempts to raise and resolve the problem of comfort girlswomen and talking about and listening to their experiences can be considered the same project but at the same time, should be considered different. Testimonies that require accurate facts can be an appropriate way to fill in the blanks in historical records, but they do not necessarily reveal the subjectivity of the oral storytellers who evaluate and interpret their own lives as the subjects of their stories. If we were to limit the interview process in gathering the experiences of comfort girlswomen to just listening to their testimonies, we could have made the mistake of paying attention to only the stories we as interviewers wanted to hear.

Unlike the serious testimonies that demand the preciseness of facts, the comfort girls-women's spoken words were brought up to the level of story or narrative to emphasize the subjective experiences they carry. This is not only to respect the subjective interpretation of those telling the story but, at the same time, to demolish the formal discourse that has been built differently to that of the victim's personal experience.

For the Japanese military comfort girls-women, to recall their past means that they are protesting against the power of history, a history which the public at large currently perceives to be the truth. According to Walter Benjamin, the history created by the remnants of the comfort girls-women's memories includes the pluralistic notion of history. And history as pluralism has many gathering points; that is, history may be diverted in various directions and be connected to different futures and presents than what exists now. According to this perspective, this book aims to reconstruct history based on each individual comfort girl-woman's experience and memories to search for critical gathering points of the past, abandoning the conventional view of history that is often objective and inevitable.

Up until now, the conflict that arose between the memories of the individual victims and the official memory of "the Japanese military comfort girls-women who 
had been taken forcefully" resulted in the former being tabooed. And the history of the Japanese military comfort girls-women, which our society recalls, has been confined to the latter. There is no such thing as the suffering of girls who were sold to brothels due to poverty and then taken to comfort stations without knowing what was going on. What difference is there in terms of its brutality and depth in the suffering of girls who were forcefully taken by the Japanese military and girls who were sold to brothels because of poverty, and then taken to comfort stations?

The problem of the Japanese military comfort girls-women arises at the contact point where the patriarchal system of the Chosun dynasty meets the nationalism of Japanese colonialism. Therefore, simplifying the problem of the comfort girls-women with the provision of 'forced abduction' hinders our understanding of the interactions between various ideologies that are contained within. Such a provision also does not allow us to view the issue of patriarchy and prostitution as another dimension of the issue of comfort girls-women while neglecting the experiences of many girls and young ladies who were sold to brothels. These girls and young ladies, who were victims of patriarchy and colonialism, have always been treated as exceptional cases and have been excluded from the Japanese military comfort girls-women issue, despite the fact that they were equally subjected to violence through sexual slavery at comfort stations by the Imperial Japanese Army. This is because the concept of Japanese military comfort girls-women was formed with too much focus on the enforcement of the forced transporting process. In this book, however, by moving beyond the preexisting understanding of Japanese military comfort girls-women that is centered around forcibleness in how they were taken away, we propose that its concept should be reconstructed by focusing on the memories of the comfort girls-women themselves and their actual experiences of sexual slavery in the comfort stations.

Being conscious of this problem, in this book, we intend to abandon the modifier, forced seizure, and start highlighting the personal experiences that have been excluded from the framework of national discourse. In other words, we want to reconstruct the history of the individual victims through their story, which has never been publicized within the grand discourse.

However, the historicization of memory does not mean that we erase and place the memory of the comfort girls-women within the discourse of nationalism. The process of speaking and listening to the comfort girls-women experience in and of itself is a challenge to the existing discourse of history, and it opposes identifying the experiences of the surviving victims of the comfort girls-women in a singular manner and as part of the discourse of nationalism. To historicize the experiences of Japanese military comfort girls-women is an attempt to bring back their experiences as the history of women that had been owned exclusively by national history, and to see the nation again in the eyes and memories of the victims. 


\section{To Speak About the Experiences of the Japanese Military Comfort Girls-Women}

When the interviewers asked the Japanese comfort girls-women survivors for their oral stories, their responses were very diverse. Some were saddened by the fact their stories were not included in the previous books that had been published and asked us why we had to come so late, while others were reluctant to have us even visit them. For those who seemed very welcoming, doing the interview meant that they would become known in their neighborhoods because after being introduced in the media, it is often the case that people start to recognize them and treat them with more respect. There was one who was very proud and had her registration of comfort girls-women kept in picture frames and displayed on the walls in her living room. Although, since we assumed that they would still be affected by a long-term victim mentality, we expected that they would be passive in sharing their stories about themselves, it did not take us long before we realized how wrong and hasty we were as we saw them actually lead the interviews. In fact, to these women, their past seemed to be a source of power that allowed them to overcome their present realities. Once they received the certificate of registration that they were comfort girls-women and started to share their past, they regained their 'joie de vivre' and, in some cases, were healed even of long-term illnesses. This tells us that the very act of speaking out about their past is in itself a process of healing.

But still, a large number of comfort girls-women survivors were not happy about their private lives coming to the surface. Our research team had focused on the surviving victims who had never been included in the past publications, but they were often reluctant to be interviewed. Their main reason for it was that they were afraid of their families and friends finding out about their past. The interviewers tried their best to explain how meaningful this work was to history, but such efforts were powerless against those who cried out, "History is good, but I have to live first." Even in the cases of those who reluctantly said yes to the interview, the interviewers would only be allowed to visit their homes when there was no one else around, or they requested that the interview take place elsewhere, away from their home. In such cases, they started revealing their stories only after they had been assured several times that we would not disclose any information that revealed their identity.

For many of the comfort girls-women survivors, their past remained a shameful experience that they should keep hidden in their hearts until their death. They often blamed themselves and experienced guilt for living a deceitful life, keeping their secret from their husbands and their children. Such internal anxiety, even today, sixty years or so after their experience, still manifests 
itself in nightmares or mental illnesses such as schizophrenia. Their experience of sex slavery has never been buried with history; rather, it is like a ghost that keeps coming back to haunt them to this day.

It has long been considered taboo for comfort girls-women survivors to talk about their experiences. And although it was imposed on them by the patriarchal Korean society, oblivion was their way of survival. Their confessions like "although it is unfair, I am being liberated [from my past experiences]" and "I could not live if I were to remember it all" are testaments to the fact that oblivion was their choice and their survival method to endure their harrowing life experiences. Therefore, the process of remembering their "true but unreal and dreamlike” past is a difficult journey for them, like going through a foggy maze, because it is what they had tried so hard to forget. This journey is the process of facing the root of their pain, and their act of telling the story meant reproducing and being re-traumatized by that pain. This is why it required a special decision and a great determination by them to start sharing their past.

But speaking out about the comfort girls-women experience in Korean society is not just a matter of a personal decision by them to open their mouths. The oral stories of surviving comfort girls-women are intertwined with multiple layers of a complex web. For the comfort girls-women, speaking of their past could mean risking a divorce from their husbands, bruising the hearts of their children, and engraving a scarlet letter onto their hearts, to name just a few. Sometimes the opposition from their community members, the so-called other husbands such as their sons, adopted sons, and nephews whom they psychologically and financially relied on, would cause them to change their minds even after coming to a hard-won decision to share their stories.

Even if the restoration of pride, the sense of historical duty, and the subsidies received from the government form an axis that motivated them to voice their experiences, the negative glances of and keeping in check of them by society and their family form another axis that creates anxiety, constantly making them hesitant about revealing their identity as a comfort girl-woman. The oral testimonies of the surviving victims of the comfort girls-women experience were born out of constant restlessness, conflict, and torments between the two axes. Therefore, the act of speaking out, for the comfort girls-women survivors, is the act of breaking out from the aforementioned complex web and rejecting the chain of silence that had been tied around them. To speak about their own lives that they were "ashamed of but are not shamed by" is an act of subjectivity away from the patriarchal ideology that Korean society has been spreading and imposing on them and the rest of the Korean society. 


\section{Problems in the Reproduction and Editing process of Oral Statements}

Having broken out of their complex web, the stories of comfort girls-women survivors enter into the field of history writing as they are textualized at the hands of researchers. The textualization of their oral stories does not mean a literal dictation of what is spoken. It is inevitable that the researchers will intervene in this process because the oral text will include the who, their purpose, and their political intention, from which point of view the story will be heard and reproduced. Thus, the reproduction of the oral story is a collaborative work of narrators and researchers entering together into a new chapter of historical discourse.

If the narrator first reproduced her own experiences and memories through an interviewer, the interviewer would then reproduce for a second time by creating a transcription that includes the description of their gestures, facial expressions, silences, etc. during the interview to minimize the loss or damage to the original story provided by the narrator. Then, the third reproduction or final compilation is the re-edited version of this secondary reproduction based on the transcription with a consideration of its readability for the readers. All of these three steps are reproductions of a story based on one person's experiences and memories; however, they are new productions, each in different forms and domains. In particular, if the transcription is a matter of how well the interviewers remember the interview situation, the editorial process is a question of how effectively the narrator's story is formulated with the reader's understanding in mind.

At the beginning of the compilation process, our research team agreed to formulate the oral text in a way that does not compromise the memory structure of the narrator. What was important to us was not how much or how accurately they remembered the facts. What we wanted to hear from them and what we hope to convey to our readers is not only the factual memory of the narrator, but also things like the structure of the narrator's memory, i.e. who is speaking, what is being remembered, what is being left unspoken within the boundaries of social discourse, and in what form are they recalling their memories? In other words, this book is not the testimony of people who witnessed an event, but a story being told at the present time, many decades after the experience, and thus it is conveyed based on each victim's unique memory structure about what they experienced and how that experience shaped their lives. However, the team gradually realized how it was too much to ask for the readers, who were not present at the interviews, to follow the narrator's memory structure. We realized that in order for us to really empathize with the reader as he or she tries to follow the stories of the narrator, we need to first discern what stories to include and what stories to let go, as some of these stories were provided to us in the forms of entangled memories, distorted 
and unclear at times due to dementia, and sometimes cautiously broached due to their politically sensitive nature. So, this book, while it is based on the experiences and memories of the narrators, is a selection of stories according to the research team's understanding and interest, as well as possibly according to how our society viewed the Japanese military comfort girls-women in 2003.

Working on this current edition, our research team also came up with new principles for editing. Deviating from our original plans to focus on minimizing the changes to the memory structure of the narrator, we decided instead to incorporate the editing intervention points created by the editor. We came to acknowledge the fact that while the interview process was led by the narrator, the structure of editing had to be under the authority of an editor; and hence, we decided to focus on how we could reveal where the editor's intervention had occurred.

The first points of intervention are indicated primarily by subheadings and titles. Subheadings and titles will serve as a guide to help the readers to read text composed of stories that are not necessarily structured and ordered. Although most of these subheadings and titles came from the narrator's story, the narrator did not necessarily give her story in this context. These are simply signs created by the editor in consideration of the readers to help with the readability of the text.

The second point of intervention we discussed was whether or not to include interview questions. The point was made that it could be misleading not to include the interview questions because this can leave the impression that the narrator is giving her story directly to the readers in a very fluent and structured manner. Needless to say, without the guiding interview questions, it is a very difficult job to put the story together by just hearing what the narrator has to say. Regardless, the interview questions used were deliberately removed during the editing process in order to reveal the subjectivity of the narrator; that is, the narrator herself is the one reproducing her own experience. However, during the interview, of course, the interviewer engaged in the reproduction of the experience by asking questions to stimulate the memory of the narrator and actively intervened throughout the making of the transcripts and edits to bring the experience back to the reader. The most important thing for us to consider was who the narrator is, and to whose experience the story belonged. Even if the authority of editing belongs to the interviewer, the fact that the subject of the experience and representation is the speaker cannot change. If the interview questions used were to be included in this work, there may be confusion between the intention of the interviewer and the voices of the narrators and result in diluting the voice of the narrator as the subject of experience and reproduction. Therefore, in order to clearly communicate the actual voices of the narrators, we deliberately left out the interview questions, and so they are not included. 
Instead, we tried to actively utilize square brackets and parentheses to help the readers' understanding. We limited the use of footnotes outside the text to only the things that required a lengthy explanation, while simple dialects, directives, and actions are described in square brackets and parentheses within the text to help the readers' understanding of words and of phrases that require explanations.

The intervening points that replace the questions are also indicated by quotation marks. The idea of using these quotation marks has been borrowed from The History Rewritten Through Memories, vol. 4: Forcibly Taken Korean Military 'Comfort Women' (Pulbit Publishing Co., 2001; hereafter Testimony Vol. 4). In Testimony Vol. 4, quotation marks were used to indicate the narrators' direct message to the reader, as well as signs of the narrator reproducing herself in stories. While we accommodated its usage, we extended it to include a broader meaning when compared to Testimony Vol. 4. The quotation marks we used were a symbol that represents the mutual subjectivity of the interview situation and the fragmentation of the transcription due to the removal of the interview questions. In other words, quotation marks were used to indicate the editor's intervention points and restructuring of the story. In addition, readers will be able to observe through the single quotes, or double quotes, in the stories the parts in which the narrator was either struggling to share her story or was actively voicing out. In this way, the quotation marks are symbols that both reveal the intervention points of the editor and the reality of the fragmentation of the oral story.

However, the quotation marks were not used just as a symbol for oral situations. These marks also symbolize the unfamiliarity that cannot be avoided when using the language that expresses women's experiences in our society. Until now, we are so used to hearing men's experiences in the language that they created that we are unfamiliar with speaking and listening to women's experiences. Language comes from recognition. Thus, having no language means one cannot fully recognize the events or experiences they had. For example, most victims of Japanese military comfort girls-women can only express their terrible experience of gang rape in the language of "it" or "received," and we have naturally accepted these two languages of "it" and "received." The comfort girls-women victims have been influenced not to recognize "it" as gang rape, and therefore, they cannot express their experience as being "raped." We are also so accustomed to recognizing, hearing, and using the phrase "lost chastity," i.e. the responsibility rests on girls instead of the perpetrators, that we would be shocked to hear them saying that they were raped. In this way, under the structure of a patriarchal society, women have been marginalized into having a language that feels strange or unfamiliar when speaking and listening to their experiences. As a result, in spite of the similarity of experiences between women in the past and us living today, we experience unfamiliarity when women or we ourselves put 
our experiences into language. Therefore, the meaning of the quotation marks used in this book represents not only the mutual subjectivity of the interview situation and the fragmentation of the transcription process but also the "unfamiliarity" in the process of the linguisticization of the female experience. We trust that this unfamiliarity/strangeness will start disappearing along with the quotation marks once women have a language where their experiences can be expressed.

Finally, the intervention points of the research team appear in the Interviewer's Commentary section. We included this section to show how this work was completed through the interactions in the narrator and interviewer relationships and by the conditions and situations in which the oral interview took place. Therefore, the readers will be able to find additional information in the Commentary section, such as the personal relationships of the narrator and the interviewer, or a context other than the oral text, for example, a story that was not explained in the text or was forced to be deleted for personal or political reasons. We also included the experiences of the difficulty the editors had to go through in the process of hearing and editing their stories. However, of course, there were personal matters of the narrators that needed to be kept secret, and which could not be revealed even in the interviewer's commentary. Also, there are cases in which we received permission to interview before the interviews began, but the narrators, having changed their minds by the time the interviews were over, became opposed to having their story published in the book and thus these were not included in the book. Apart from the interviewers' commentary, we also included the failed cases, because we considered the process and the context of comfort girls-women victims rejecting interviews or publications as another form of their testimony. Through the failed cases, readers will find out how difficult a fight it is for the comfort girls-women victims to share their experiences and suffering and for others to hear their stories.

There were also some controversies in the process of writing the interviewers' commentaries. Notably, we had great difficulty in coming to an agreement on how we should refer to the comfort girls-women. Each team member insisted on their own reasons for addressing them differently, such as halmoni (grandmother), her, or by their names. In general, halmoni is the common term used to refer to the Japanese military comfort girls-women since halmoni is a friendly term and has the advantage of making the comfort girls-women more approachable, as they are otherwise associated with a very somber image. However, those who opposed the use of the term halmoni argued that halmoni has a negative image in Korean society of one who is weak, asexual, and always willing to yield to others in everything. They asserted that using the term halmoni contradicts the goal of our work of acknowledging each individual victim as an independent person with dignity rather than understanding them as a single group of comfort girlswomen by again making the mistake of grouping them into the fixed image of 
halmonis. Therefore, some argued for using the pronouns 'her/she' instead of halmoni to escape the grouped stereotypes surrounding the Japanese military comfort girls-women. Nonetheless, the team members that wanted to use halmoni claimed that halmoni is what we called them during the interviews and insisted that we stay true to our personal relationships with them. They continued to press that that is how it should be presented in the Interviewers' Commentaries. Moreover, we were just listeners, and the oral speaker/narrator is the subject of the speech during the interview, and it would feel as if we were objectifying them if we were to use the third person pronouns 'her/she.' These team members also explained how using the term halmoni would not mean that we blindly accepted the stereotype of halmoni in Korean society. Rather, it would explain in an active sense what the interview situation was: it was not about our observation of the narrator, but an interaction between the narrator and interviewer. Our research team decided to open up and share this problem with our readers instead of trying to come up with one single term upon which we can all agree.

\section{An Unfinished Story}

More than seventy years have passed since the issue of the Japanese military comfort girls-women was first raised, and it has been more than a decade since this issue truly became an important topic in our society. In the meantime, the survivors of the Japanese military comfort girls-women have been living their lives in hiding like sinners and appearing as victims. But at the same time, they also stepped up as activists, leading the way in order to resolve this issue. This process of survival was not only a way of confronting and overcoming their sufferings but also a process of healing from their hurts of one another.

But then, what answer have they received for their survival efforts from the Japanese government, the perpetrating nation, and also from our Korean society? Have their voices been given proper attention? The surviving victims are saddened by the few remaining days in their lives, and they talk about the still remaining or newly added wound of $\mathrm{han}^{1}$ in their hearts. They speak of uncompensated pasts, conflicts in their relationships with family and others, and how this society is adding new suffering to their lives by being indifferent to their issue. Surely, this is not because the voices of the surviving victims have been weak for more than a decade. Rather, it is because the Japanese government and the Korean society have either avoided and ignored their voices or distorted the truth.

1 Anger, grief, or resentment that is repressed without any resolution. 
March 17, 2004 marked the 600th gathering of the Wednesday rallies in front of the Japanese embassy every week. Every time the Wednesday rally faces its anniversary or the total number of gathering increases by another 100, rally participants grieve with heavy hearts and hope that there will not be another anniversary. However, this will only occur when the Japanese government makes an official apology and offers appropriate compensation. In reality, however, the Japanese government remains unresponsive through their continued silence on this issue. Even worse, they seem to be dreaming of the resurgence of militarism by distorting history and intentionally removing any mention of the Japanese military comfort girls-women from their textbooks. The Japanese government is poised to repeat their past crimes, as they try with immense effort to rationalize the Japanese military comfort girls-women system by telling blatant lies, such as "Comfort girls-women were prostitutes" and "There was no forced recruitment of comfort girls-women."

The narrow nationalism in Korean society is also a factor that slows down the resolution of the Japanese military comfort girls-women issue. As we know, nationalism was the main factor of the rapid growth in the public discussion of the issue of comfort girls-women. In the early 1990s, Korean society recognized the essence of this problem as the loss of the nation's innocent cheonyeo (a virgin and unmarried girl/young lady) to the Japanese government due to Chosun's failure to defend her country, and it urged for a resolution of this issue in order to restore the nation's pride. In the mid-1990s, this nationalist perspective was attacked by the feminist claim that such a patriarchal nature of nationalism prevents us from seeing the issue of the contradicting sexual ethics of the Korean patriarchy that is intricately intertwined with the Japanese military comfort girls-women. However, their cry was not enough to break the existing view. In the dualistic view of sexual ethics that only emphasizes the chastity of girls and women and the male-centered sex culture of Korean society, the problem of sexual ethics surrounding the issue of comfort girls-women is still not considered. Korean society only raised the problem of comfort girls-women in the category of nationalism, and seriously narrows the scope of the Japanese military comfort girls-women issue by merely addressing the aforementioned lies of the Japanese government by responding, "Comfort girls-women were not prostitutes and innocent cheonyeo" and "Comfort girls-women were forcefully taken against their will by means of kidnapping and fraud."

In fact, whether or not comfort girls-women were prostitutes, or whether or not they were forcibly taken, is not the essence of the comfort girls-women issue. Even those who were already kisaeng (professional courtesans with artistic skills) or working at a licensed quarters before becoming a comfort girl-woman, or those who thought they were going to be making money at a bar, had no idea that they would be forced to live such an inhuman life in "that place." They did not know how brutally they would be sexually abused by the Japanese soldiers in such 
confined spaces where they could not possibly even think of escaping, and they also did not know how much they were to suffer. Could anyone claim that there is no perpetrator in their suffering if we were to think outside of our stereotypical image of the Japanese military comfort girls-women? Let us remember that, from the outset, the issue, the content, and the character of the Japanese military comfort girls-women problem have been revealed by the surviving victims by recalling their memories. What is at the heart of this issue is the fact that girls and young ladies have been subjected to continuous sexual violence and suffered human rights violations at comfort stations that the Japanese military created for the efficient control of their soldiers during wartime. The category of the Japanese military comfort girls-women should be constructed from the experiences of the survivors, not from the defensive logic against Japanese claims. The voice of the sufferings of the surviving victims will not be heard unless we start reflecting on the dualistic view of Korean society's sexual ethics and the patriarchal attitude of nationalism that our society holds. As long as we see the issue of comfort girlswomen essentially as an issue of shame for the male-centric Korean nation that failed to protect their girls and young ladies because it had lost its power, as long as this nation recognizes only those who kept their chastity as worthy of protection, and as long as we keep asking victims of rape to prove their chastity and forcedness, the fundamental solution to the issue of Japanese military comfort girls-women will not come about.

The huge controversy that stirred in February 2004 around the release of a collection of nude videos and pictures themed around the comfort girls-women demands a new reflection on the Japanese military comfort girls-women issue. Basically speaking, the comfort girls-women issue is a case of state-led systemic sexual violence, but the way this case is being handled in our society is no different from any other case of rape. In other words, the rape case focuses only on the sexual aspect rather than on the victim's suffering. People are curious about the situation in which the victim is being raped and try to meet an individual's sexual fantasies through concrete reproductions of the situation. In the same way, the commercial press, too, is just busy trying to profit by responding to the expectations of the public by using stimulating expressions and titles in reporting the case. The way they deal with the Japanese military comfort girls-women problem is no different. While the mass media pretended to care, using the theme of the solemnity of the nation's suffering, they only focused on how cruelly and forcefully the comfort girls-women were taken, how many soldiers each had to "receive" in a day, and how helplessly they were exposed to violence, while having no consideration for the victims themselves, whether they were ready to share their stories, or whether it was the appropriate place for sharing them. As they took out their cameras and journals for writing, instead of hearing what 
they wanted to share, they poured out only the questions related to what they wanted to hear. We were honestly asking ourselves whether we were stimulated by the shocking content provided by the media. It is most likely that the content creator that planned the themed nude videos and pictures about comfort girlswomen was also aware of this reality of our society, i.e. numbness to the sexual violation and ensuing suffering of women. The abusive view that our society holds, that even tries to commercialize women's sexual abuse and secretly takes pleasure in the suffering of women, demands our serious reflection and criticism.

How far have we come regarding this issue of the Japanese military comfort girls-women? Frankly speaking, the social awareness surrounding this issue seems not to have changed much since more than a decade ago, despite various efforts being made and questions raised as the stories of the surviving victims of the Japanese military comfort girls-women have been made available. In addition to the stubborn nationalist view, dual ethics and hypocrisy in regard to female sexuality, and the patriarchal system that gave birth to all of the above, simply propel us to selectively hear what we want to hear and do not allow us to hear the stories of comfort girls-women in the way they render themselves. Unless we can go beyond the limits of our society, the stories of the surviving Japanese military comfort girls-women will remain empty cries. We hope that this book does not just become the sixth edition of repeated stories, but a sixth story that broadens the horizon of our recognition and reflection.

May 10, 2004

The Research Team

War \& Women's Human Rights Center 